\title{
Introduction: New Perspectives on John Ogilvie's Martyrdom, the Society of Jesus, and Scottish Catholicism during the Sixteenth and Seventeenth Centuries
}

\author{
Paul Goatman ${ }^{1}$ \\ University of Glasgow \\ p.goatman.1@research.gla.ac.uk
}

\begin{abstract}
The Society of Jesus's mission in Scotland lasted from 1581 until the papal suppression of 1773 , yet the Jesuits' impact on religious life there during this period remains an underexplored aspect of Scotland's early modern history. The articles in this special issue offer fresh perspectives on the mission, with particular attention paid to one of its most dramatic and controversial events - the trial and execution of John Ogilvie for treason in Glasgow during the autumn and winter of 1614-15. Fresh insights are provided here on Ogilvie's martyrdom from the perspective of local and international politics and Jesuit theology. The familiar theme of the Jesuits' attempted conversion of James VI and I is also revisited, and new research is presented on Catholicism in seventeenth-century Scotland in articles about the Jesuits' work in the Highlands and their appeal to the memory of the medieval Queen Saint Margaret. Overall, this issue attests to historians' enduring fascination with John Ogilvie's martyrdom and what it can teach us about religion, politics and society in early modern Scotland, and the potential of the Jesuits' activities there as a rich field for future research.
\end{abstract}

1 I wish to thank Robert Maryks for allowing me the opportunity to edit this special issue of $J J S$ and for his immense patience as the issue has been put together. I would also like to thank the contributors to this issue, who have been similarly patient and amenable about the timescale and editorial changes to their work.

(C) PAUL GOATMAN, 2020 | DOI:10.1163/22141332-00701001

This is an open access article distributed under the terms of the prevailing CC-BY-NC-ND 4.0 license. 


\section{Keywords}

Jesuits - early modern Scotland - John Ogilvie - James VI and I - martyrdom - Scottish Catholicism - Counter-Reformation - sixteenth and seventeenth centuries

The articles in this special edition explore the inter-relationship between the Jesuit mission to Scotland during the sixteenth and seventeenth centuries and the evolution of post-Reformation Scottish Catholicism. In doing so, they offer a range of fresh perspectives on the period. Despite scholars' ongoing work, notably the pioneering archival work of Thomas McCoog, this relationship remains an under-explored aspect of Scotland's "long Reformation."2 From December 1581, the Society of Jesus maintained a continuous, if low-key presence in Scotland for almost two centuries until the papal suppression of 1773 , and their work during this time has yet to be studied systematically. ${ }^{3}$ Throughout the period, the Jesuits were typically amongst the most active of the Catholic missionaries working in Scotland but the resources they were able to devote to their work nevertheless always remained limited. It has been estimated, for instance, that the number of Jesuits in Scotland only ever averaged between six and ten between 1580 and $165^{0 .}{ }^{4}$ This lack of resources and the generally hostile environment that faced the Jesuits in Scotland meant that they tended to take a highly-focused approach and worked with, rather than against, the pre-existing grain of indigenous Scottish Catholicism. From this perspective, the spectacular execution of John Ogilvie (b.1579) in Glasgow on February 28, 1615 stands out as a stark and anomalous example of the Jesuits' endeavors in Scotland (Figure 1). Many, although not all, of the six articles in this special issue were commissioned following a conference held in Glasgow, organized

2 See for example, Thomas McCoog, The Society of Jesus in Ireland, Scotland and England, 15411588: "Our Way of Proceeding?" (Leiden: Brill, 1996); McCoog, The Society of Jesus in Ireland, Scotland, and England, 1589-1597: Building the Faith of Saint Peter upon the King of Spain's Monarchy (Farnham: Ashgate, 2012); McCoog, The Society of Jesus in Ireland, Scotland, and England, 1598-1606: "Lest Our Lamp be Entirely Extinguished" (Leiden: Brill, 2017); for the paradigm of Scotland's "long Reformation," see Scotland's Long Reformation: New Perspectives on Scottish Religion, c.150o-c.166o, ed. John McCallum (Leiden: Brill, 2016).

3 McCoog, The Society of Jesus in Ireland, Scotland and England, 1541-1588, 182; McCoog, "The Society of Jesus in the Three Kingdoms," in The Cambridge Companion to the Jesuits, ed. Thomas Worcester (Cambridge: Cambridge University Press, 2008), 88-103, here 98. The Jesuits would maintain a continued presence in Scotland until the papal suppression of 1773 .

4 Narratives of Scottish Catholics under Mary Stuart and James VI, ed. William Forbes-Leith (London: T. Baker, 1889), 145. 


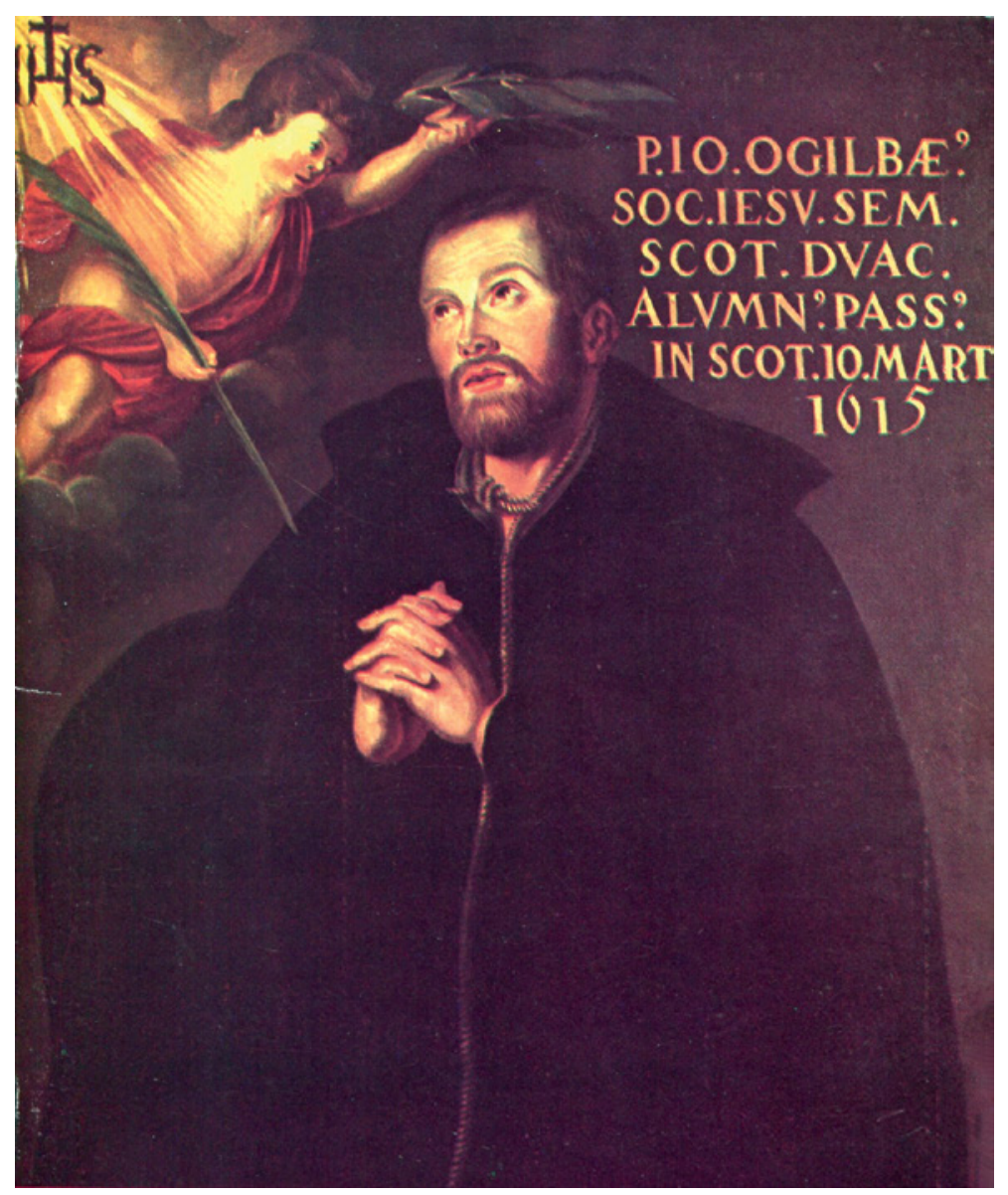

FIGURE 1 This portrait of John Ogilvie hung at the Scots College at Douai, France until its closure in 1762. Today, it is in the parish church of Saint Gilles at Pecquencourt

by the Scottish Religious Cultures Network, to commemorate the quatercentenary of Ogilvie's death in 2015. Three of them present new perspectives on his trial and offer some answers to the question of why Ogilvie was put to death when the execution of Catholics was so rare in post-Reformation Scotland. The other three articles shed light on perhaps more general facets of the Society's presence in Scotland between 1581 and 1773 .

By way of introduction, it may be helpful to outline something of the ebb and flow of the Jesuit presence in Scotland during this period. The sources indicate that the Society injected renewed energy and resources into the mission at various points. Toward the end of 1628 , for example, John Leslie (d.1635) wrote the first of what would become a series of annual reports on the Scottish 
mission to Superior General Muzio Vitelleschi (1563-1645; in office 1615-45). His main focus was a sudden increase in anti-Catholic persecution instigated the previous year by King Charles I (160o-49; r.1625-49), in an attempt to distract attention from the unpopular implementation of his revocation scheme by vigorously enforcing anti-Catholic penal laws that had lain dormant on the statute book since $1609 .{ }^{5}$ Leslie also described some of the mission's recent successes, stating that the arrival in Scotland in 1617 of his elder brother, William Leslie (d.1639), who had become superior of the mission, assisted by James Lindsay and Patrick Stickel, had invigorated the Jesuit cause there. However, he also complained that the long period prior to this had seen Jesuits take too lenient an approach with Scotland's Catholics, allowing them to attend the kirk and even receive Protestant Communion. ${ }^{6}$ According to Leslie, this had "occasioned many not bad Catholics to make a lamentable shipwreck of their faith." His account indicates that the attitudes of the Jesuits themselves changed in relation to Scotland and that they frequently saw fit to change their approach to promulgating and nurturing the Catholic faith there.

Monographs by Thomas McCoog and Michael Yellowlees have further highlighted the Jesuits' changing attitudes to Scotland. They focus on the heady early years of the Scottish mission, before the 1603 Union of Crowns, when the Society concentrated its attention and resources on the royal court of King James VI (1566-1625; r.1603-25) and their attempts to convert him to Catholicism, and enjoyed the support of the Spanish crown and the French noble House of Guise. ${ }^{8}$ This early period of the mission saw some success as James's

5 Memoirs of Scottish Catholics during the XVIIth and XVIIIth Centuries, ed. William ForbesLeith, 2 vols (London: Longmans, Green, 1909-10), I, 25-40; Allan Macinnes, "Catholic Recusancy and the Penal Laws, 1603-1707," Records of the Scottish Church History Society 23 (1987): 27-63, here 41. Charles's revocation scheme was an attempt to reclaim for the crown all royal or church land that had been alienated since the death of James $\mathrm{V}$ in 1542.

6 Forbes-Leith, Memoirs of Scottish Catholics, I, 18; R. Scott Spurlock, "Scottish Catholicism in the Age of John Ogilvie," unpublished paper given at the Glasgow meeting of the Newman Society (2015).

7 Forbes-Leith, Memoirs of Scottish Catholics, I, 15.

8 McCoog, Society of Jesus in Ireland, Scotland and England, 1541-1588; McCoog, Society of Jesus in Ireland, Scotland and England, 1589-1597, 368-75; Michael Yellowlees, "So strange a monster as a Jesuit": The Society of Jesus in Sixteenth-Century Scotland (Isle of Colonsay: House of Lochar, 2003), 148-51; McCoog, "Pray to the Lord of the Harvest': Jesuit Missions to Scotland in the Sixteenth Century," Innes Review 53, no. 2 (2002): 127-88, here 143, 154, 157; Yellowlees, "Father William Crichton's Estimate of the Scottish Nobility, 1595," in Sixteenth-Century Scotland: Essays in Honour of Michael Lynch, ed. Julian Goodare and Alasdair A. MacDonald (Leiden: Brill, 2008), 295-310. 
queen, Anna (1574-1619; r.1590-1619), was converted from Lutheranism by 1596, and members of the high nobility either converted or became further committed to the old faith. But the king resisted the efforts at his conversion made by early Scottish Jesuit pioneers such as William Crichton (c.1535-1617), and although the king tended to adopt a tolerant stance toward Catholicism in this period, he did so for political reasons and was equally liable to persecute them when he saw fit. ${ }^{9}$ The year 1603 marked a crucial turning point for the mission, when the removal of the royal court to England and the death in French exile of Archbishop of Glasgow James Beaton (1524-1603), the last of the preReformation Catholic hierarchy, forced the Society to rethink its Scottish strategy. From then on, resources allocated to Scotland tended to be diverted to the Scots' colleges on the continent and to sending smaller numbers of more highly trained priests on the mission. ${ }^{10}$ Jesuit efforts in Scotland were further hampered by a lack of centralized organization from Rome. Although the Congregation for the Propagation of the Faith, founded by Pope Gregory XV (15541623; r.1621-23) in 1622, included jurisdictional responsibility for Scotland from the following year, no apostolic prefect would be appointed there until 1653 and no Roman Catholic bishop until 1694. In any event, the Society chose to work independently in Scotland for the most part and often found itself in competition with Dominicans and secular clergy operating in the kingdom, which further weakened Catholic unity.11

Precisely because of the disorganized nature of the Counter-Reformation in Scotland and the lack of resources available to the mission, Scott Spurlock has recently argued that post-Reformation Catholicism survived in Scotland largely free of outside involvement and was therefore "Scoto-centric rather than Romano-centric in focus." He has shown that post-Reformation Scottish Catholicism depended upon the patronage and protection that could be

Yellowlees, "So strange a monster as a Jesuit," 150-51; Maureen M. Meikle and Helen Payne (2008) "Anne [Anna, Anne of Denmark] (1574-1619), Queen of England, Scotland, and Ireland, Consort of James VI and I," Oxford Dictionary of National Biography [ODNB], ed. H. C. G. Matthew and Brian Harrison (Oxford: Oxford University Press, 2004) (accessed September 9, 2019).

10 Thomas McInally, The Sixth Scottish University: The Scots Colleges Abroad, 1575 to 1799 (Leiden: Brill, 2012), 6-10, 20-30, 69-71; McInally, "Support Networks for the Catholic Mission in Scotland," Innes Review 65, no. 1 (2014): 33-51, here 41-45; McCoog, "Pray to the Lord of the Harvest," 157-59; McCoog, "The Society of Jesus in the Three Kingdoms," 98-99.

11 R. Scott Spurlock, “I do disclaim both Ecclesiasticke and Politick Popery': Lay Catholic Identity in Early Modern Scotland," Records of the Scottish Church History Society 38 (2008): $5^{-22}$, here 13-14. 
provided by the laity, particularly the high nobility and gentry. ${ }^{12}$ Nowhere was this more apparent than in the north-east of Scotland, where the protection afforded by staunchly Catholic noble families, especially the Gordon Earls of Huntly (Marquises from 1599) (George, first marquess of Huntly, 1561/2-1636; George, second marquess of Huntly, c.1590-1649; Lewis, third marquess of Huntly, c.1626-1653; George, fourth marquess of Huntly, 1643-1716), meant that the region became a stronghold for the old faith. Architectural features can still be found in the homes of powerful regional families, which point to a strong Jesuit influence throughout the seventeenth century and demonstrate that Catholicism played an important role in supporting aristocratic familial and corporate identities in the north-east at that time. Inscriptions of the Jesuit IHS monogram can still be found in castles at Fetternear, Balquhain, and Beldorney that belonged to the Leslie family during the seventeenth century. Castles at Craig, Gight and Towie Barclay in Aberdeenshire, properties owned by the Huntly Gordons during the sixteenth and seventeenth centuries, also house cross-shaped gun loops and depictions of arma Christi. These were examples of Catholic iconography common across Europe during the sixteenth and seventeenth centuries, which Ian Bryce and Alasdair Roberts have described as "symbol[s] of traditional, embattled, Christianity."13 Similarly, a coat of arms produced in 1605 for the entrance to Huntly Castle depicts not only the family arms, but also images of the five wounds of Christ, the Virgin Mary, and St. John, and Latin text taken from Galatians 6:14, which declares: "God forbid that I should glory save in the cross of our Lord Jesus Christ." Above this sits an image of the risen Christ alongside the inscription: "I rise again with Divine Power." The Scottish Lion and the double-headed eagle of the Holy Roman Empire can be seen on either side. ${ }^{14}$ Such iconography shows us some of the ways in which Catholicism could sustain aristocratic family identities in Scotland during this period and underpin understandings of national and even pan-national identity. Nor was Catholic survival of this kind restricted to the

12 Spurlock, "I do disclaim both Ecclesiasticke and Politick Popery," 5-22, quotation at 21; also see Spurlock, "The Laity and the Structure of the Catholic Church in Early Modern Scotland," in Insular Christianity: Alternative Models of the Church in Britain and Ireland, c.1570-c.170o, ed. Robert Armstrong and Tadhg Ó hAnnracháin (Manchester: Manchester University Press, 2013), 231-47 for further elucidation of these arguments.

13 Ian Bryce and Alasdair Roberts, "Post-Reformation Catholic Symbolism: Further and Different Examples," Proceedings of the Society of Antiquaries of Scotland 126 (1996): 899-909, quotation at 908.

14 Spurlock, "Scottish Catholicism in the age of John Ogilvie." 
"conservative north-east." Allan Macinnes has shown that between the Union of Crowns and the accession of James VII $\left(1633^{-1701 ; ~ r .1685-89) ~ i n ~} 1685\right.$, the heads of at least 169 landed families in the Lowlands were indicted by the state for recusancy. ${ }^{15}$ This evidence testifies to the aristocratic environment within which the Jesuits chose to work and their success in cultivating the practice of Catholicism amongst Scotland's noble classes. ${ }^{16}$

The picture painted above is one of Jesuits who worked quietly within the homes of Scotland's noble and gentry families and enjoyed their patronage, avoiding as far as possible the attentions of the kirk and an embryonic and often insecure British state, which saw persecution of Catholics as a convenient way to strengthen its position. This image corroborates the view put forward by Macinnes, who has stated that between 1603 and 1707 Catholicism "posed no sustained nor serious threat to the civil or religious establishment."17 But in this context, how should we interpret the arrest, imprisonment, trial, and eventual execution of Ogilvie, the events of which unfolded over the winter of 1614-15? This issue attempts to provide some answers to that question. Despite its dramatic nature, Ogilvie's trial and execution awaits a modern study. ${ }^{18}$ Daniel MacLeod has recently led the way in revisiting Ogilvie's martyrdom and has provided some fruitful new interpretations. First, he has argued that in order for Ogilvie's death to be understood in its proper historical context, religious belief must be placed firmly back at the center of the narrative. Through an

15 Allan Macinnes, "Catholic Recusancy and the Penal Laws," 30; For the idea of the "conservative north-east" of Scotland in this period, see Gordon Donaldson, "Scotland's Conservative North in the Sixteenth and Seventeenth Centuries," Transactions of the Royal Historical Society 16 (1966): 65-79; Donaldson, Scottish Church History (Edinburgh: Scottish Academic Press, 1985), 193-96; Bruce McLennan, "Presbyterianism Challenged: A Study of Catholicism and Episcopacy in the North East of Scotland, 1560-1650," 2 vols. (PhD diss., University of Aberdeen, 1977).

16 In 1628, John Leslie stated that although there were only six Jesuit priests working in Scotland, they all lived within the households of powerful Catholic families. Father William lived in the Earl of Errol's residence in Cruden Bay; Patrick Stickwell with George Gordon, first Marquis of Huntly; James Macbreck with the Earl of Wintoun; Robert Valens with the Earl of Abercorn and George Christie with the Countess of Linlithgow. Forbes-Leith, Narratives of Scottish Catholics, 9-10.

17 Macinnes, "Catholic Recusancy and the Penal Laws," 35.

18 The standard work on Ogilvie remains William E. Brown, John Ogilvie: An Account of His Life and Death with a Translation of the Documents Relating Thereto (London: Burns Oates \& Washbourne, 1925). See Mark Dilworth, "The Counter-Reformation in Scotland: A Select Critical Biography," Records of the Scottish Church History Society 22 (1984): 84-100, here 91, for other work on Ogilvie in the Innes Review, most of which was carried out by Dilworth and John Durkan during the 1980 . 
examination of aspects of Ogilvie's education on the continent and his communications with Archbishop of Glasgow John Spottiswood (1565-1639) and King James VI and I during his trial, MacLeod has shown that Ogilvie actively pursued his own death, in an attempt to claim his place in the pantheon of Catholic martyrs. ${ }^{19}$ His work is also a response to a recent tendency amongst those historians who have commented on Ogilvie and his mission to "oversecularize" his trial, downplay the religious motivations of the protagonists involved and accept the royal narrative that he was put to death purely for treason. It is certainly true that Ogilvie himself wanted religion to be at the heart of any understanding of his trial. As he was led to the scaffold, he is said to have exclaimed: "I am delivered up to death for religion alone."20 This statement highlights another argument made by MacLeod that the propaganda stemming from Ogilvie's trial should be given greater attention. Ogilvie's statement on the way to the scaffold was pure propaganda and consistent with his other attempts to control the way in which his execution was understood. MacLeod has shown that a propaganda war escalated between the Jesuits and the British state immediately after the trial. The publication of Ogilvie's Relatio incarcerationis et martyrii P Ioannis Ogilbei natione Scoti e Societate Jesu presbyteri, printed at Douai in 1615, first presented his version of events. He wrote the Relatio during his period of imprisonment in Glasgow and began circulating the work by passing sections of it through the bars of his cell to visitors who had come to see him. ${ }^{21}$ The government response came swiftly in the form of Spottiswood's own account, which was published in his A True Relation of the Proceedings againstJohn Ogilvie later during $1615 .{ }^{22}$ MacLeod's work therefore offers us new vantage points on Ogilvie's martyrdom and ways to better understand what remains a contested and controversial event and one highly unusual in postReformation Scotland.

The authors who have contributed to this special edition make no claim to an authoritative new history of Ogilvie's life or martyrdom, the Jesuit mission between 1581 and 1773 or the evolution of post-Reformation Scottish Catholicism. Rather, they present a series of highly focused research articles that offer fresh perspectives on all of these subjects and show that as a whole, this field

19 Daniel MacLeod, "Declining His Majesty's Authority: Treason Revisited in the Case of John Ogilvie," in McCallum, Scotland's Long Reformation, 179-201.

20 John Ogilvie, S.J., An Authentic Account of the Imprisonment and Martyrdom of John Ogilvie, trans. Charles Karslake (London, 1877), 48; MacLeod, "Declining his Majesty's Authority," 179 .

21 MacLeod, "Declining his Majesty's Authority," 180.

22 MacLeod, "Declining his Majesty's Authority," 181. 
should be considered a rich one for future research. Thomas McCoog begins by revisiting early Jesuit attempts to convert King James VI. This updates his previous work on the early mission, and he argues here that William Crichton and other Jesuits present at the royal court harbored hopes for his conversion even after the Gunpowder Plot of 1605. In doing so, McCoog presents for the first time two memorials penned by Crichton: De missione in Scotiam pro conversione regis (Concerning a mission to Scotland for the conversion of the king), written during the early 1580 s, and a later, untitled work that McCoog dates to the period between James Drummond's $(c .1580-1611)$ elevation to the earldom of Perth in March 1605 and the new oath of allegiance introduced by King James in June 1606.

Three articles then follow that explore some of the reasons why Ogilvie was put to death during an era in which Catholic priests and lay Catholics in Scotland were generally spared this fate. Allan Macinnes approaches the issue from an international perspective, showing that as the new ruler of a composite "British" monarchy after 1603, James VI and I positioned himself as the foremost defender of Protestantism in Europe. As the king pursued this project, no challenge to his authority could be tolerated, whether from Rome, the Holy Roman Emperor or Presbyterian dissenters and in particular, the status of the newly re-established Scottish episcopate could never be compromised. Ogilvie posed such a direct and unyielding threat to the bishops that the state ultimately deemed his death necessary in order to preserve their authority. In the next article, Paul Goatman turns to the local context for Ogilvie's mission and shows us that a number of unique political and social factors combined so that an influential Catholic community was able to survive in Glasgow after the Reformation Parliament of 1560 . This community supported the Jesuit during 1614-15 and continued to thrive in the town long after his death. Mark Elliott then demonstrates how Ogilvie's intransigence in the face of Archbishop Spottiswood and the British state was based on intellectual foundations as much as Ogilvie's personal qualities of bravery, principle and religious piety. As he pursued his own death, he demonstrated an interpretation of the New Testament espoused by Jesuit theologians such as Juan Maldonado (1533-83), who had argued that fleeing persecution could never be an option for a true Jesuit pastor.

The final two articles turn to the later seventeenth century and Jesuit influences on the development of Scottish Catholicism. Mary Horan shows us that in order to honor King Charles II's (1630-85; r.166o-85) restoration in 166o, the Society of Jesus published and circulated a small devotional book entitled L'Idée d'une reine parfaite, written about Queen Saint Margaret of Scotland (c.1045-93; r.1070-93), King Malcolm III's (1058-93; r.1070-93) consort. This work proved popular amongst Catholics in Scotland and Europe more widely 
and was translated into English in 1661, Italian in 1675, and Spanish in 1679. Horan's study presents us with a new perspective on the role that the Jesuits played in disseminating Catholic ideas in Scotland during the seventeenth century. In the final article, Alasdair Roberts explores an under-appreciated aspect of the Jesuits' work in Scotland in this period, the Highland mission. ${ }^{23}$ He shows how the Jesuits worked hard, often in forbidding circumstances, to sustain Catholicism in the Highlands from the late sixteenth century until the suppression, providing a reliable presence there and proving popular with their congregations.

Considered together, these articles demonstrate that the Jesuits maintained an important influence in Scotland for nearly two hundred years, despite their limited numbers and lack of resources. The pieces showcase the quality of scholarship currently being undertaken in this area and the close reading of archival sources demonstrated throughout shows that the available source base can sustain any number of detailed studies. The Jesuits played a vital role in the survival and evolution of Scottish Catholicism between 1560 and the suppression of 1773 and the period as a whole and Ogilvie's martyrdom in particular are shown here to be subjects ripe for future research.

23 Although see Fiona Macdonald, Missions to the Gaels: Reformation and CounterReformation in Ulster and the Highlands and Islands of Scotland, 1560-1760 (Edinburgh: John Donald, 2006). 